\title{
RESEARCH PAPER \\ Botryosphaeriaceae species affecting table grape vineyards in Chile and cultivar susceptibility
}

\author{
Andrea Morales ${ }^{1}$, Bernardo A. Latorre ${ }^{2}$, Eduardo Piontelli ${ }^{3}$, and Ximena \\ Besoain $^{1}$ \\ ${ }^{1}$ Facultad de Agronomía, Pontificia Universidad Católica de Valparaíso, Casilla 4-D, Quillota, Chile. \\ ${ }^{2}$ Facultad de Agronomía e Ingeniería Forestal, Pontificia Universidad Católica de Chile, Casilla 306-22, \\ Santiago, Chile. \\ ${ }^{3}$ Facultad de Medicina, Universidad de Valparaíso, Casilla 92-V, Valparaíso, Chile.
}

\section{Abstract}

A. Morales, B.A. Latorre, E. Piontelli, and X. Besoain. 2012. Botryosphaeriaceae species affecting table grape vineyards in Chile and cultivar susceptibility. Cien. Inv. Agr. 39(3): 445-458. Several Botryosphaeriaceae species have been identified as the causes of cankers and dieback of Vitis vinifera in several grape-growing regions around the world. This research was conducted to further study the species of Botryosphaeriaceae associated with table grapes in Chile, to estimate the prevalence and severity of the disease as a function of vineyard age, to study the susceptibility of table grape cultivars to infection by Botryosphaeriaceae species, and to evaluate the effect of tissue age on the infection caused by Botryosphaeriaceae species. Symptoms were characterized by the presence of the partial or total death of the grapevine cordons and distorted leaves. Brown V-shaped or U-shaped cankers and black spots were observed in cross-sections, while brown vascular streaks were observed in longitudinal sections of the cordons and trunks. Pathogenic isolates of Diplodia seriata, D. mutila and Spencermartinsia viticola were consistently obtained from wood cankers and/or vascular streaking; D. seriata was the most common (83.3\%) Botryosphaeriaceae species. In 11- to 20 -year-old vineyards, the disease incidence varied between 22.0 and $69.0 \%$, and the severity varied between 6.0 and $21.3 \%$. The table grape cultivars 'Thompson Seedless', 'Redglobe' and 'Flame Seedless' were equally susceptible to infection by D. mutila, D. seriata and S. viticola. The age of the inoculated tissue had no significant effect on the development of the vascular necrosis. This is the first report of D. mutila and S. viticola infections of grapevines in Chile.

Key words: Diplodia, grapevine diseases, Spencermartinsia viticola, trunk diseases, Vitis vinifera.

\section{Introduction}

Table grapes (Vitis vinifera L.) are high-value export crops cultivated on 55,119 ha across a range of diverse climate zones in Chile. 'Thomp-

Received: March 5, 2012. Accepted July 17, 2012.

Corresponding author: xbesoain@ucv.cl son Seedless', 'Flame Seedless' and 'Redglobe' are the most prevalent cultivars planted in Chile (ODEPA, 2009).

Several grapevine trunk diseases have been described worldwide including Botryosphaeria cankers, black dead arm (BDA), esca, excoriose, and Eutypa dieback (Bulit et al., 1972; Lehoczky, 
1974; Moller and Kasimatis, 1978; Latorre et al., 1986; Mugnai et al., 1999; Larignon et al., 2001; Phillips et al., 2005; Úrbez-Torres et al., 2006; Úrbez-Torres and Gubler, 2009; Úrbez-Torres, 2011). Many studies have associated canker diseases with the presence of Botryosphaeriaceae species, Diatrypaceae species, and Phomopsis viticola (Sacc.) Sacc. (Moller and Kasimatis, 1978; Larignon and Dubos, 1997; Armengol et al., 2001; Phillips, 2002; Auger et al., 2004; Trouillas et al., 2010). BDA was identified for the first time in Hungary by Lehoczky (1974), who associated this disease with Diplodia mutila Fr. (as Botryosphaeria stevensii Shoemaker). Later it was reported in Italy (Cristinzio, 1978), where the disease was associated with $D$. seriata De Not. (as B. obtusa Schwein. Shoemaker), and later in France (Larignon et al., 2001), where it was associated with $D$. seriata and $B$. dothidea (Moug.:Fr.) Ces \& De Not. However, Chamberlain et al. (1964) were the first to suggest the role of D. seriata (as Sphaeropsis malorum Peck.) in the etiology of wood cankers of grapes.

The aims of the present study were 1. to further study the Botryosphaeriaceae species associated with the dieback in table grape vineyards in Chile, 2. to estimate the prevalence and severity of the disease as a function of vineyard age, 3 . to evaluate the susceptibility of table grape cultivars to infection by Botryosphaeriaceae species, and 4 . to study the effect of tissue age on the infection caused by Botryosphaeriaceae species.

\section{Materials and methods}

\section{Sampling locations and fungal isolations}

Fungal isolates were obtained from grapevines showing decline, small and distorted leaves and chlorosis. The isolations were performed between July 2008 and April 2009 from a total of 79 samples taken either from wood necrosis or vascular streaking from the following table grape cultivars: 'Thompson Seedless', 'Redg- lobe', 'Crimson Seedless', 'Flame Seedless' and 'Superior'. The samples were collected from 22 vineyards located between Ovalle (lat. $30^{\circ}, 37^{\prime}$, S) and Paine (lat. $33^{\circ}, 55^{\prime} \mathrm{S}$ ).

Small pieces of wood $\left(<1 \mathrm{~cm}^{2}\right)$ were selected from the margins both of V-shaped cankers and black spots observed in the cross-sections of affected arms. The samples were disinfected for $30 \mathrm{~s}$ in $95 \%$ ethanol, rinsed with sterile distilled water (SDW), dried and plated onto potato dextrose agar (PDA) plates acidified with $0.5 \mathrm{~mL}$ per liter of $96 \%$ lactic acid (APDA). The plates were incubated at $24{ }^{\circ} \mathrm{C}$ for at least 5 days or until fungi were observed growing from the symptomatic wood. The hyphal tips were sub-cultured in water agar (WA) and then transferred to APDA. The isolates were maintained in SDW at $5^{\circ} \mathrm{C}$.

\section{Morphological characterization}

To stimulate sporulation, the isolates were cultivated on autoclaved lignified 1-year-old apple twigs ( $2 \mathrm{~cm}$ in length) placed on WA. The cultures were incubated for 5 days at $24^{\circ} \mathrm{C}$ in the dark and for an additional 45 days at room temperature $\left(18-22^{\circ} \mathrm{C}\right)$ under ultraviolet (UV) light $(\lambda=320 \mathrm{~nm})$. For each isolate, 30 conidia were characterized according to their shape, length, width, color, and septum development. The presence or absence of pycnidium development for each isolate in APDA at $24^{\circ} \mathrm{C}$ was also recorded. For each isolate, ten conidiogenous cells were measured, and colony characterization was also performed. For species identification, the taxonomic key proposed by Phillips (2007) was used.

\section{Molecular characterization}

Genomic DNA was extracted from 3- to 4-day-old cultures using a DNeasy Plant Mini Kit (Qiagen GmbH, Duesseldorf, Germany). The internal transcribed spacer (ITS) was amplified, including the 5.8S gene of the nuclear ribosomal DNA, using 
primers ITS1 and ITS4 (White et al., 1990). The polymerase chain reaction (PCR) was performed in a thermal cycler (BIOER, TC-96/T/H(a), Bioer Technology Co. LTD, Tokyo, Japan), as described by Úrbez-Torres et al. (2008). The PCR products were separated by agarose gel electrophoresis (100 $\mathrm{V}$ for $60 \mathrm{~min}$ ) at $1.5 \%$ in $1 \times$ Tris-Acetate-EDTA buffer (TAE) (40 mM Tris, $40 \mathrm{mM}$ acetate, $2 \mathrm{mM}$ EDTA, pH 8.0). Each electrophoresis included 0.5 $\mu \mathrm{L}$ of a $100 \mathrm{bp}$ marker (BioLabs Inc., San Diego, $\mathrm{CA})$. The gel was then stained with ethidium bromide for $20 \mathrm{~min}$ and visualized using a UV transilluminator (Vilber Lourmat, Marne-laVallée, France).

The PCR products with bands between 500 and $600 \mathrm{bp}$ in size were purified using the Axyprep PCR Clean-up kit (Axygen Biosciences, California, USA) and were sequenced in both directions (Pontificia Universidad Católica de Chile, Santiago, Chile). The ITS sequences of 24 isolates were aligned with the multiple sequence alignment program MAFFT version 6 (Katoh et al., 2005). Additional sequences were selected from GenBank (Table 1) by BLAST searches and included in the alignment. The phylogenetic analysis using parsimony was performed with PAUP* Version 4.0b10 for Macintosh (Sinauer Associates, Inc., Publishers, Sunderland, MA, USA). The analysis consisted of heuristic searches with 1,000 repetitions of random terminal addition of sequences, keeping only 20 non-optimal phylograms. Branch swapping was performed using tree bisection-reconnection (TBR). All characters were considered non-ordered and of equal weight. Indels were treated as missing data. The internal support of the clades was evaluated by 1,000 bootstrap (BS) replications (Felsenstein, 1985) with 10 repetitions of random terminal addition sequences and branch swapping using TBR, keeping up to 20 of the most parsimonious trees.

To confirm the morphological identifications, the ITS sequences obtained from 24 isolates of Botryosphaeriaceae from Chile were aligned with the ex-type sequences of D. mutila, $D$. seriata, S. viticola, Dothiorella (Do.) iberica and Do. sarmentorum from GenBank (NCBI, 2009) (Table 1); Mycosphaerella populorum (isolate AF 216533) and M. africana (isolate AF 283690) were used as outgroups.

\section{Incidence of Botryosphaeriaceae wood infections in table grapes}

In 2009, the presence of Botryosphaeriaceae species was determined in seven table grape vineyards with vines between 11 and 20 years of age belonging to the following cultivars: 'Thompson Seedless', 'Redglobe' and 'Crimson Seedless' (Table 2). The grapevines were grown on own-roots, with the exception of 'Redglobe' (grafted on 'Harmony'), on high trellis systems supported on overhead arbors $2 \mathrm{~m}$ in height. To associate external symptoms with internal symptoms, at least three grapevines in each vineyard were examined internally, and isolations were made from $\mathrm{V}$-shaped or U-shaped cankers and/or black spots yielding Botryosphaeriaceae species. Consequently, quadrants of 100 plants were randomly selected, and each plant was rated according to its external symptoms. The incidence was estimated as the percentage of diseased grapevines over the total number of grapevines. The severity was estimated using a 0 to 4 scale, in which $0=$ healthy plant, $1=$ one diseased cordon (from only one stunted shoot to the death of the entire cordon), $2=$ two diseased cordons, $3=$ three diseased cordons and $4=$ four diseased cordons. The severity was expressed as a damage index (DI) (Mc Kinney, 1923): DI = ( $(\mathrm{nv})(\mathrm{VN})-1100)$ where, $\mathrm{n}=$ number of arms per degree of attack; $\mathrm{v}=$ degree of attack; $\mathrm{N}=$ total number of arms observed; $\mathrm{V}=$ maximum range of the attack scale. In addition, grapevines from each vineyard were sampled to determine the presence of Botryosphaeriaceae species that were identified morphologically and molecularly. The relationships between plant age and percent incidence and between plant age and percent severity were studied by regression analysis. 
Table 1. Sequences of species of Botryosphaeriaceae used in the phylogenetic analysis.

\begin{tabular}{|c|c|c|c|c|c|}
\hline Species & $\begin{array}{l}\text { Collection } \\
\text { Number }^{1} \\
\end{array}$ & $\begin{array}{l}\text { No Accession } \\
\text { Genbank }\end{array}$ & Origin & Hosts & References \\
\hline \multirow[t]{5}{*}{ Diplodia mutila } & CBS 112553 & AY259093.2 & Portugal & Vitis vinifera & Alves et al. (2004) \\
\hline & UCD 288Ma & DQ008313.1 & California & Vitis vinifera & Úrbez-Torres et al. (2006) \\
\hline & STE-U 5824 & EF445346.1 & South Africa & Prunus salicina & Damm et al. (2007) \\
\hline & STE-U 5038 & AY343484 & South Africa & Vitis vinifera & van Niekerk et al. (2004) \\
\hline & WAC 11082 & AY727838 & Australia & Vitis vinifera & Taylor et al. (2005) \\
\hline \multirow[t]{9}{*}{ Diplodia seriata } & UCD $614 \mathrm{Tu}$ & DQ008318.1 & California & Vitis vinifera & Úrbez-Torres et al. (2006) \\
\hline & UCD 710SJ & DQ008321.1 & California & Vitis vinifera & Úrbez-Torres et al. (2006) \\
\hline & STE-U 5899 & EF445336.1 & South Africa & Prunus persica & Damm et al. (2007) \\
\hline & CMW 1050 & DQ836723.1 & South Africa & Prunus communis & Slippers et al. (2007) \\
\hline & UCD 1035BC & EU012379.1 & Mexico & Vitis vinifera & Úrbez-Torres et al. (2008) \\
\hline & CMW 7775 & AY236954 & USA & Ribes sp. & Slippers et al. 2004 \\
\hline & STE-U 4581 & AY343439 & South Africa & Vitis vinifera & van Niekerk et al. (2004) \\
\hline & STE-U 5037 & AY343446 & South Africa & Vitis vinifera & van Niekerk et al. (2004) \\
\hline & CBS 112556 & AY259096 & Portugal & Pyrus communis & Alves et al. (2004 \\
\hline Diplodia sp. & SET-U 5048 & AY343373 & South Africa & Vitis vinifera & van Niekerk et al. (2004) \\
\hline \multirow[t]{8}{*}{ Spencermartinsia viticola } & CBS 117010 & AY905558.1 & Spain & Vitis vinifera & Luque et al. (2005) \\
\hline & UCD 1642Yo & EF202010.1 & California & Vitis vinifera & Úrbez-Torres et al. (2007) \\
\hline & CBS 117008 & AY905557.1 & Spain & Vitis vinifera & Luque et al. (2005) \\
\hline & SET-U 6139 & $\mathrm{EF} 445360.1$ & South Africa & Prunus persica & Damm et al. (2007) \\
\hline & STE-U 5831 & EF445361 & South Africa & Prunus salicina & Damm et al. (2007) \\
\hline & CBS 117009 & AY905554 & Spain & Vitis vinifera & Luque et al. (2005) \\
\hline & CBS 117006 & AY905555 & Spain & Vitis vinifera & Luque et al. (2005) \\
\hline & CBS 117007 & AY905556 & Spain & Vitis vinifera & Luque et al. (2005) \\
\hline \multirow[t]{9}{*}{ Dothiorella iberica } & JL 384 & AY573211.1 & Spain & Malus pumila & Phillips et al. (2005) \\
\hline & CBS 115036 & AY573216.1 & Spain & Quercus suber & Phillips et al. (2005) \\
\hline & JL 220 & AY573215.1 & Spain & Quercus ilex & Phillips et al. (2005) \\
\hline & CBS 115039 & AY573210 & Italy & Quercus sp. & Phillips et al. (2005) \\
\hline & JL 366 & AY573209 & Italy & Quercus sp. & Phillips et al. (2005) \\
\hline & CBS 113189 & AY573199 & Spain & Quercus ilex & Phillips et al. (2005) \\
\hline & DE 27 & AY573200 & Spain & Quercus ilex & Phillips et al. (2005) \\
\hline & CBS 113188 & AY573198 & Spain & Quercus suber & Phillips et al. (2005) \\
\hline & CBS 115035 & AY573213 & Spain & Quercus ilex & Phillips et al. (2005) \\
\hline \multirow[t]{4}{*}{ Dothiorella sarmentarum } & CBS 164.33 & AY573208.1 & Unknown & Prunus americana & Phillips et al. (2005) \\
\hline & IMI $63581 \mathrm{~b}$ & AY573212.1 & England & Ulmus sp. & Phillips et al. (2005) \\
\hline & CBS 115038 & AY573206.1 & Netherland & Malus pumila & Phillips et al. (2005) \\
\hline & CBS 120.41 & AY573207 & Norway & Pyrus communis & Phillips et al. (2005) \\
\hline
\end{tabular}

${ }^{1}$ Acronyms of culture collections: CBS: Central Bureau Schimmel cultures, Utrecht, Netherlands; CMW: Culture Collection Forestry and Agricultural Biotechnology Institute, University of Pretoria, South Africa; WAC = Department of Agriculture Western Australia, Plant Pathogen Collection; STE-U: Department of Plant Pathology, University of Stellenbosch, South Africa; UCD: University of California, Davis, Plant Pathology Department Culture Collection; JL: J. Luque IRTA, Barcelona, Spain; DE: M.E. Sánchez, University of Córdoba, Spain; IMI: CABI Bioscience, Egham, U.K. 
Table 2. Incidence and severity of dieback symptoms in table grapes (Vitis vinifera) in Chile.

\begin{tabular}{lcccc}
\hline Locations & Cultivars & Plantation Year & Incidence $^{1}(\%)$ & Severity $^{2}(\%)$ \\
\hline Champa & Thompson Seedless & 1989 & 69 & 21.3 \\
San Bernardo & Thompson Seedless & 1991 & 41 & 12.3 \\
Mallarauco & Thompson Seedless & 1993 & 57 & 21.8 \\
San Bernardo & Thompson Seedless & 1996 & 47 & 12.5 \\
Paine & Redglobe & 1997 & 25 & 6.5 \\
Melipilla & Crimson & 1997 & 42 & 10.8 \\
Los Andes & Redglobe & 1998 & 22 & 6.0 \\
\hline
\end{tabular}

${ }^{1}$ The incidence was determined in a 100 plant sample per vineyard. ${ }^{2}$ The severity was estimated according to a damage index (see text).

\section{Cultivar susceptibility}

The pathogenicity and relative susceptibility of the table grape cultivars 'Thompson Seedless', 'Redglobe' and 'Flame Seedless' to infection by D. mutila (isolate VID 1265), D. seriata (isolate VID 1270) and Spencermartinsia viticola (isolate VID 1286) were determined by the length of the necrosis and vascular streaking obtained in detached 1-year-old shoots ( $25 \mathrm{~cm}$ in length) during dormancy. The shoots were surface disinfected (1\% sodium hypochlorite for $5 \mathrm{~min}$ and $95 \%$ ethanol for $30 \mathrm{~s}$ ) and inoculated with a 3-day-old mycelium plug (5 $\mathrm{mm}$ in diameter in APDA) that was placed under an oblique cut made aseptically in the bark with a sterile scalpel.
The inoculated area was covered with Parafilm to prevent rapid dehydration. An equal number of shoots was inoculated with $B$. dothidea (Pal 496 [=IMI 395777]), from Persea americana) as a positive control, and discs of non-colonized APDA agar plugs served as negative controls. Five shoots were used per treatment and incubated for 35 days in a humid chamber at $23^{\circ} \mathrm{C}$ (Table 3 ).

The results were subjected to analysis of variance according to a complete randomized design with a $3 \times 3$ factorial arrangement of treatments (three vine cultivars $\times$ three pathogen species). The means were separated using Tukey's test $(\mathrm{P} \leq 0.05)$. The statistical program Minitab 15 (Minitab Inc., PA, USA) was used for the statistical analyses.

Table 3. Relative susceptibility of the table grape (Vitis vinifera) cultivars 'Thompson Seedless', 'Flame Seedless' and 'Redglobe' to Botrytosphaeria dothidea, Diplodia seriata, D. mutila, and Spencermartinsia viticola, determined in inoculated in shoot cuttings.

\begin{tabular}{|c|c|c|c|c|c|c|c|c|c|}
\hline \multirow[b]{2}{*}{ Species } & \multirow[b]{2}{*}{ Isolates } & \multicolumn{4}{|c|}{ Mean necrotic length $(\mathrm{cm})$} & \multicolumn{4}{|c|}{ Mean vascular necrotic streak length $(\mathrm{cm})$} \\
\hline & & $\mathrm{TS}^{1}$ & $\mathrm{RG}^{1}$ & $\mathrm{FS}^{1}$ & Means & $\mathrm{TS}^{1}$ & $\mathrm{RG}^{1}$ & $\mathrm{FS}^{1}$ & Means \\
\hline S. viticola & VID 1286 & 1.02 & 1.28 & 1.06 & $1.1 \mathrm{a}^{2}$ & 2.98 & 1.28 & 2.02 & $2.09 \mathrm{a}^{2}$ \\
\hline D. seriata & VID 1270 & 1.88 & 1.90 & 3.98 & $2.6 \mathrm{a}$ & 4.44 & 2.34 & 8.14 & $4.97 \mathrm{a}$ \\
\hline D. mutila & VID 1265 & 4.16 & 6.48 & 4.88 & $5.2 \mathrm{~b}$ & 9.38 & 9.64 & 11.02 & $10.00 \mathrm{~b}$ \\
\hline B. dothidea & PAL 496 & 9.00 & 9.72 & 6.88 & $8.5 \mathrm{c}$ & 16.00 & 14.44 & 14.64 & $15.00 \mathrm{c}$ \\
\hline \multicolumn{2}{|l|}{ Means } & $4.01 \mathrm{ab}$ & $4.85 \mathrm{a}$ & $4.20 \mathrm{a}$ & & $8.20 \mathrm{ab}$ & $6.93 a$ & $8.96 \mathrm{a}$ & \\
\hline \multicolumn{2}{|c|}{ Analysis of variance } & $\mathrm{df}$ & MS & $\mathrm{P}$ & & $\mathrm{df}$ & MS & $\mathrm{P}$ & \\
\hline \multicolumn{2}{|c|}{ Cultivar $(\mathrm{C})$} & 2 & 3.79 & 0.49 & & 2 & 21.06 & 0.25 & \\
\hline \multicolumn{2}{|l|}{ Pathogen (P) } & 3 & 158.6 & 0.00 & & 3 & 487.37 & 0.00 & \\
\hline \multicolumn{2}{|l|}{$\mathrm{C} \times \mathrm{P}$} & 6 & 7.17 & 0.24 & & 6 & 11.06 & 0.62 & \\
\hline
\end{tabular}

'Table grape cultivars: TS = 'Thompson Seedless', RG = 'Redglobe' and FS = 'Flame Seedless.'

${ }^{2}$ Means followed by different letters indicate significant differences according to Tukey's test $(\mathrm{P}=0.05)$. No lesions were detected on the control plants. 
Effect of tissue age on wood symptom development in adult plants

This experiment was conducted in apparently healthy grapevines, selected in a 25-year-old commercial vineyard of "Flame Seedless" table grapes located in San Felipe. Non-lignified shoots ( $<1$-year-old shoots), lignified canes $(>5$ years old) and mature arms ( $>4 \mathrm{~cm}$ in diameter) were inoculated in January (summer) with $D$. seriata (isolate VID 1270) and D. mutila (isolate VID 1265) using the method described above. An equal number of grapevines were treated with sterile discs of APDA. In addition, grapevines inoculated with $B$. dothidea (isolate PAL $496=$ IMI 395777) were included for comparison. The length of the necrotic lesions and the length of vascular streaking were determined 137 days after inoculation. The results were subjected to analysis of variance according to a complete randomized design with a $3 \times 3$ factorial structure (three tissue ages $\times$ three pathogens) with five replicates each. The means were separated according to Tukey's test $(\mathrm{P} \leq 0.05)$. Prior to analysis, the lengths of the cankers were transformed using $\log (\mathrm{x})$.

\section{Results}

Symptoms, incidence and damage index

The symptoms were characterized by the presence of a partial or total death of the grapevine cordons and distorted leaves (Figure 1A). Brown U-shaped or V-shaped cankers (Figure 1B) and black spots were observed in cross-sections, while brown vascular streaks were observed in longitudinal sections of cordons and trunks. Additionally, diseased plants exhibited reduced growth in one or more cordons and death of one or more shoots (Figure 1A).

The incidence and severity of symptoms in grapevines varied from 22.0 to $69.0 \%$ and 6.0 to $21.8 \%$ in 11- and 20-year-old grapevines, respectively (Table 2). A linear model best explained the re- lationship between $\mathrm{x}=$ plant age and $\mathrm{y}=$ percent prevalence $\left(\mathrm{y}=-12.0+3.79 \mathrm{x}, \mathrm{R}^{2}=0.62, \mathrm{P}=0.05\right)$ and between $\mathrm{x}=$ plant age and $\mathrm{y}=$ percent severity $\left(y=-7.95+1.44 x, R^{2}=0.61, P=0.05\right)$ (Figure 2).

\section{Isolates and identification}

Twenty-four Botryosphaeriaceae isolates were obtained, and, based on their morphology, they were identified as D. seriata (83.3\%), D. mutila (8.3\%) and $S$. viticola $(8.3 \%)$. These species were obtained alone, mainly on samples taken in the autumn (94.7\%), followed by samples taken in the winter $(57.1 \%)$ and spring (2.2\%). These species were obtained from wedged or V-shaped perennial cankers in cordons and from black spots. The colonies of $D$. seriata, $D$. mutila and S. viticola (Figure 3B, D, F) developed dark brown pycnidia after 10 to 15 days in APDA and apple twigs. The conidia of $D$. seriata were unicellular, ellipsoidal and truncated; their mean dimensions were $22.7 \pm 0.8 \times 10.1 \pm 0.5 \mu \mathrm{m}$ (Figure $3 A)$. The conidia of D. mutila were mainly aseptate and ellipsoidal; they exhibited mean dimensions of $26.1 \pm 0.2 \times 12.2 \pm 0.6 \mu \mathrm{m}$, but dark brown, septated conidia developed in cultures after 45 days (Figure 3C). The conidia of $S$. viticola were ellipsoidal and septate; their mean dimensions were $21.5 \pm 0.4 \times$ $9.5 \pm 0.3 \mu \mathrm{m}$ (Figure 3E).

The maximum parsimony analysis of the ITS region produced 18,680 trees of 246 steps $(\mathrm{CI}=0.94$, RI $=0.98, \mathrm{HI}=0.05)$. Because of the large number of trees produced, the strict consensus tree is shown in Figure 4. The isolates from Chile were distributed over two clades: the first corresponded to the genus Diplodia with $100 \%$ bootstrap support, and the second group was composed of Dothiorella sp. and Spencermartinsia. The 19 isolates corresponding to $D$. seriata formed a moderately supported clade $(\mathrm{BS}=72)$. The remaining isolates corresponding to Diplodia were grouped with samples from GenBank corresponding to $D$. mutila. In addition, the isolates VID 1268 and VID 1286 also formed a highly supported clade $(\mathrm{BS}=98)$ corresponding to $S$. viticola (Figure 4). 

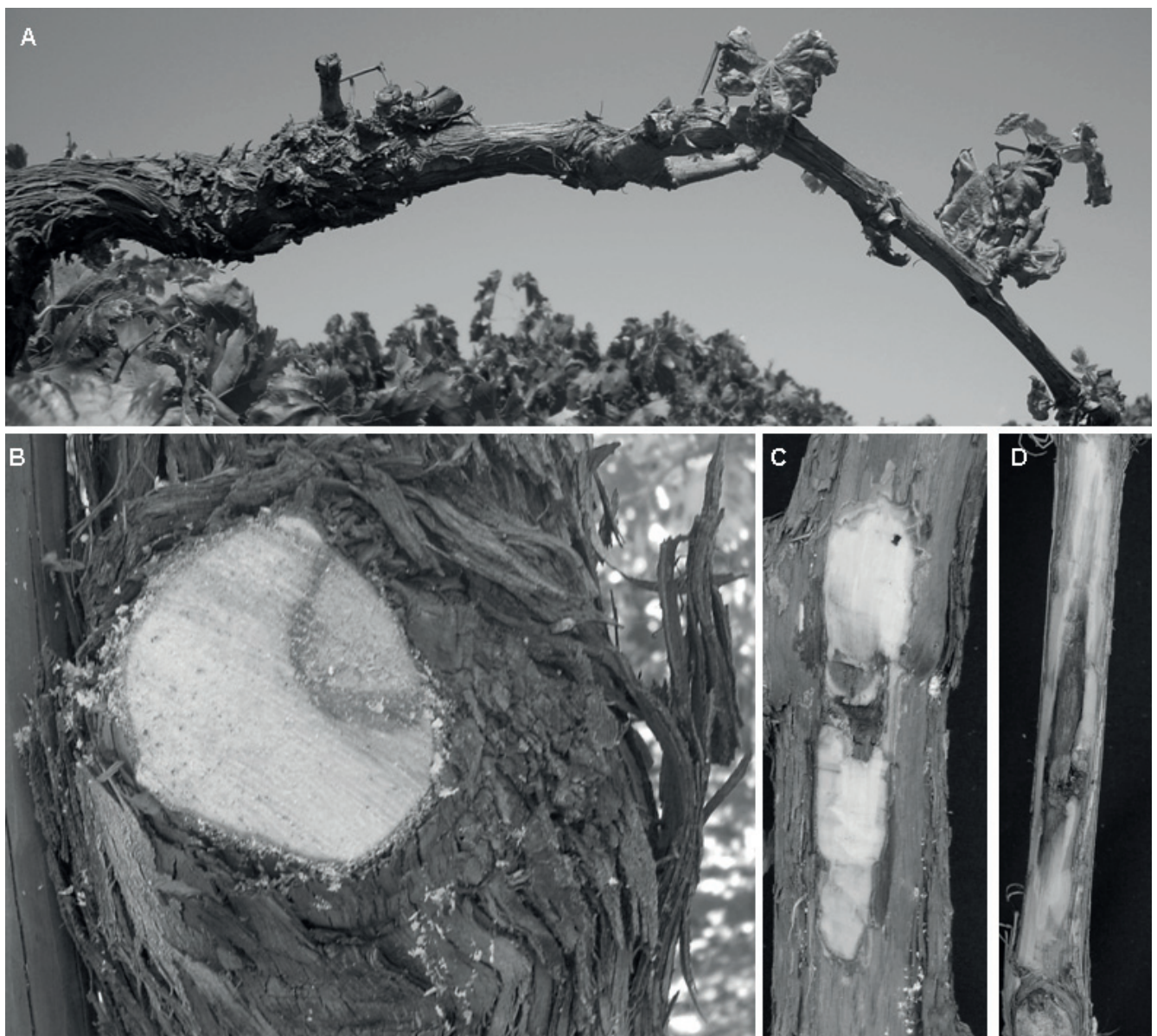

Figure 1. Symptoms caused by Botryosphaeriaceae spp. in table grapevines (Vitis vinifera). A, Partial death of a grapevine cordon with small shoots and distorted leaves associated with black dead arm observed in an 11-year-old 'Redglobe' plant. $\mathrm{B}$, Cross-section of a 16-year-old trunk of a 'Thompson Seedless' plant exhibiting U-shaped dark brown necrosis. C and $\mathrm{D}$, Necrotic lesions associated with Diplodia seriata on a mature arm (C) and D. mutila on a lignified cane (D) both from a 25-year-old 'Flame Seedless' table grape plant.

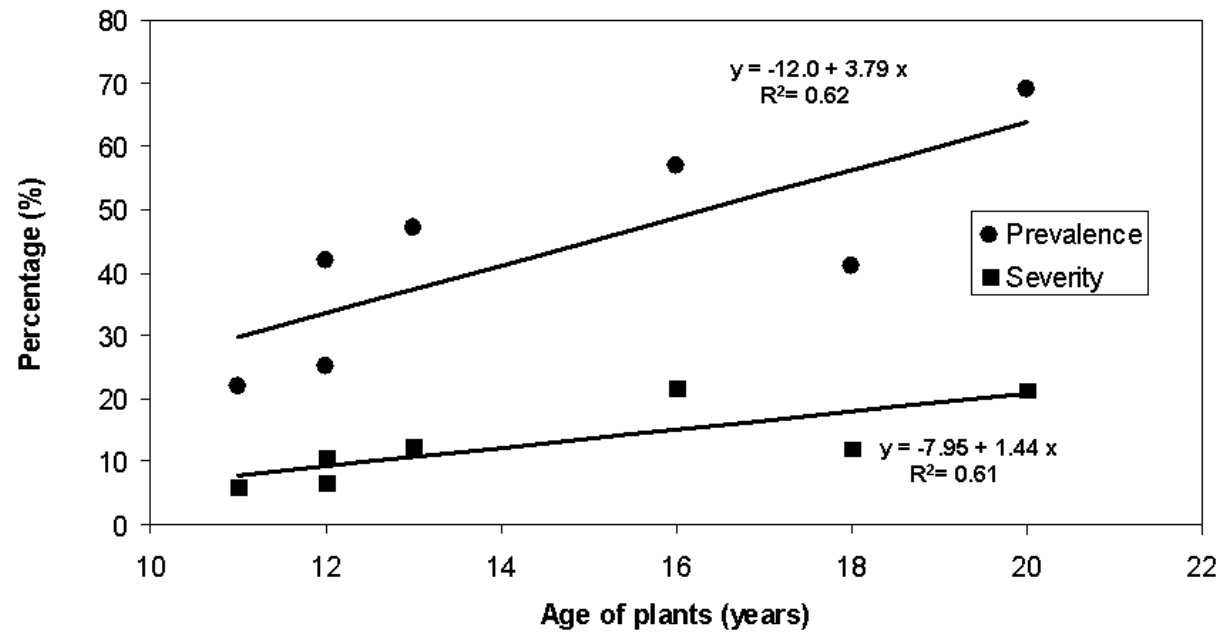

Figure 2. Relationships between the age of the vineyard and prevalence and severity of decline of table grapes (Vitis vinifera), determined in the fall of 2009. 

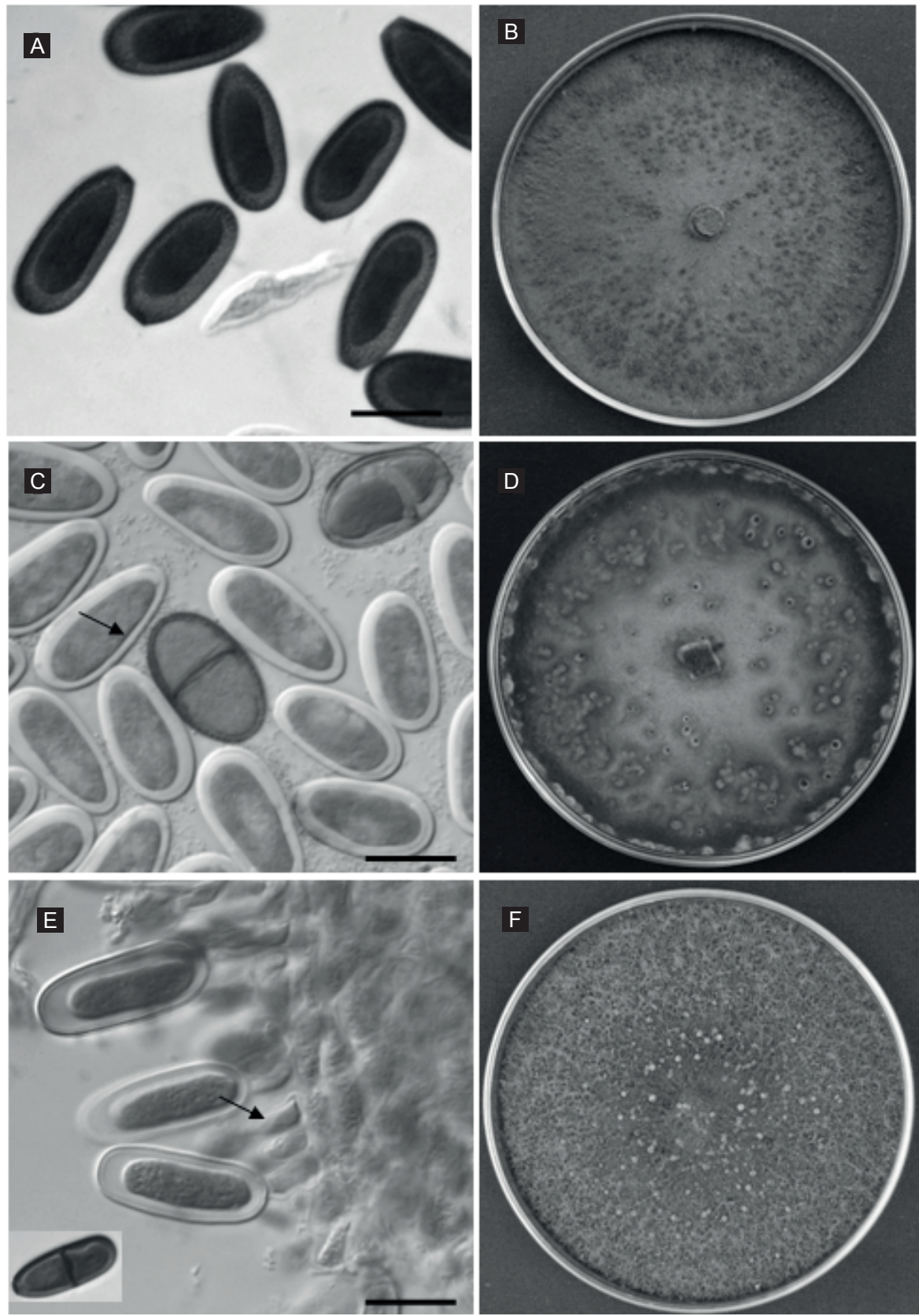

Figure 3. Morphological characteristics of Botryosphaeriaceae spp. obtained from table grapes (Vitis vinifera) in Chile. A and B, Diplodia seriata. Conidia with truncated bases and rounded tips (A) and colonies (B) in acidified potato dextrose agar (APDA) after 21 days of incubation at room temperature. C and D, Diplodia mutila. Ellipsoidal conidia (C), which are hyaline and thick-walled, and mature conidia (arrow), which are melanized, dark brown and septated. Colony in APDA after 21 days of incubation (D). E and F, Spensermartinsia viticola (anamorph Dothiorella viticola). Conidiogenous cells (arrow) and young, round, thick-walled (E) and detail of mature septated conidia, which are melanized and dark brown, with truncated bases. Colony in APDA after 21 days of incubation (F). Scale $=20 \mu \mathrm{m}$. 


\section{Cultivar susceptibility}

The isolates of D. seriata, D. mutila, S. viticola and $B$. dothidea were pathogenic on shoot cuttings of 'Thompson Seedless', 'Redglobe' and 'Flame Seedless' and produced dark brown necrotic lesions that were 1.1 to $8.5 \mathrm{~cm}$ in length. Vascular streaking that developed in the same samples varied from 2.09 to $15.00 \mathrm{~cm}$ in length (Table 3). Pycnidia were obtained in inoculated shoot cuttings above the wounds.

The effect of the pathogens on both the length of necrosis and the length of vascular streaking was significant $(\mathrm{P} \leq 0.05)$, but the effect of table grape cultivars and the interactions between the table grape cultivars and the pathogens were not statistically significant (Table 3). Among the Botryosphaeriaceae species isolated in this study, D. mutila and $D$. seriata produced the most extensive necrosis and vascular streaking, followed by $S$. viticola . However, B. dothidea appeared to be the most virulent Botryosphaeriaceae species (Table 3).

Effect of tissue age on internal necrotic lesion development in mature grapevines

After 137 days from the inoculation time, internal necrotic lesions were observed in the wood of mature 'Flame Seedless' plants; these lesions were characterized by sharp margins, and were dark brown in color. They extended acropetally and basipetally from the points of inoculation and

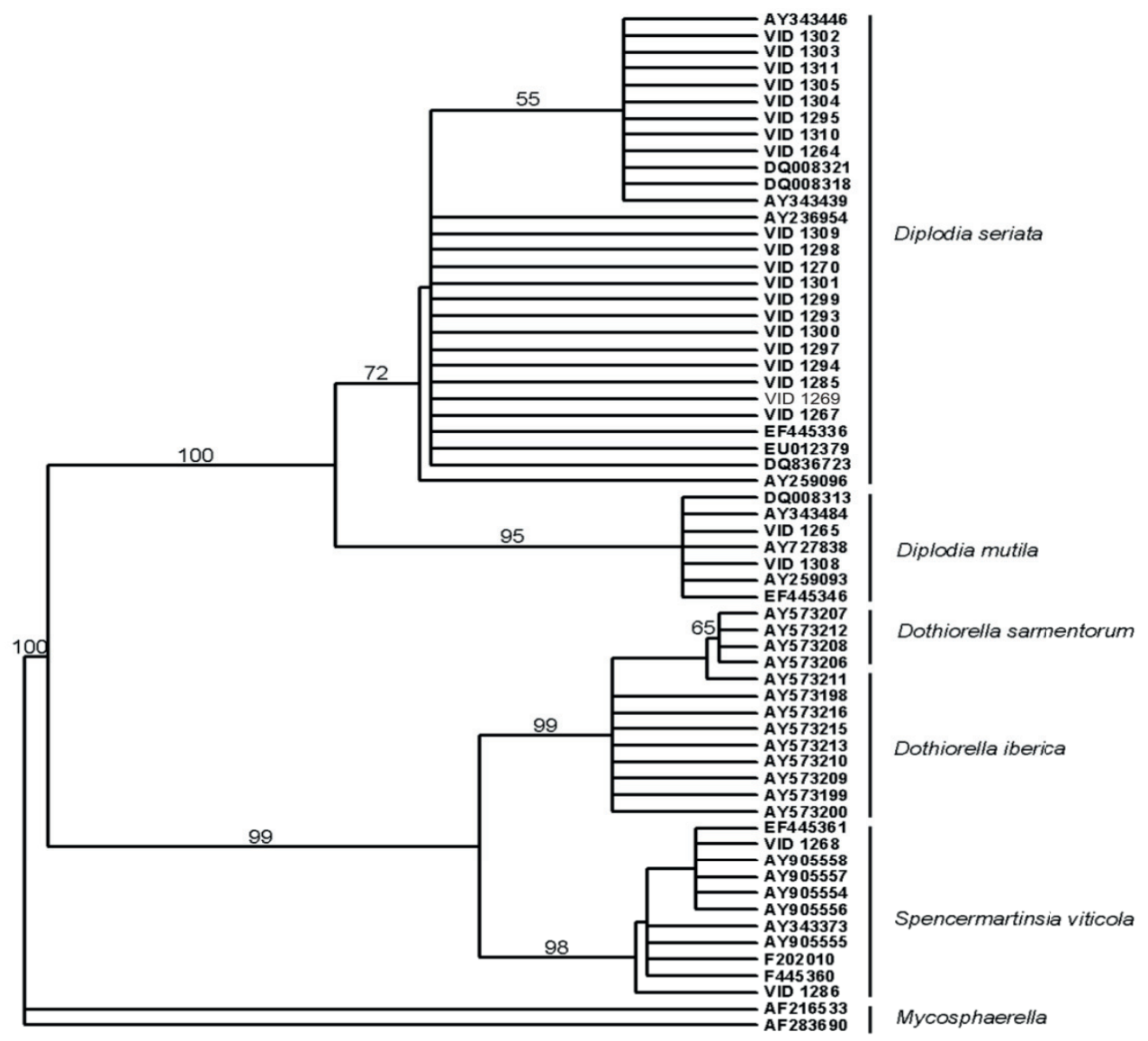

Figure 4. Strict consensus tree from analysis of the ITS region of the nuclear rDNA corresponding to isolates (VID) of Botryosphaeriaceae spp. obtained from table grapes (Vitis vinifera) in Chile. The numbers on the branches correspond to the bootstrap values $(>50 \%)$. 
Table 4. Effect of tissue age on the development of necrosis and vascular necrotic streaks produced by Botryosphaeria dothidea, Diplodia seriata and D. mutila in table grape (Vitis vinifera) cv. Flame Seedless.

\begin{tabular}{|c|c|c|c|c|c|c|c|c|c|}
\hline \multirow[b]{2}{*}{ Species } & \multirow[b]{2}{*}{ Isolates } & \multicolumn{4}{|c|}{ Mean necrotic length $(\mathrm{cm})$} & \multicolumn{4}{|c|}{ Mean vascular necrotic streak length $(\mathrm{cm})$} \\
\hline & & 1 Year & 2 years & $>5$ years & Means & 1 Year & 2 years & $>5$ years & Means \\
\hline B. dothidea & PAL 496 & 1.52 & 3.10 & 2.64 & $2.42 \mathrm{a}^{1}$ & 8.50 & 9.80 & 6.50 & $8.27 \mathrm{a}^{1}$ \\
\hline D. seriata & VID 1270 & 2.28 & 2.72 & 4.92 & $3.31 \mathrm{ab}$ & 9.78 & 12.30 & 12.00 & $11.36 \mathrm{~b}$ \\
\hline D. mutila & VID 1265 & 4.50 & 4.38 & 3.16 & $4.01 \mathrm{~b}$ & 9.04 & 10.50 & 8.48 & $9.34 \mathrm{ab}$ \\
\hline Means & & $2.77 \mathrm{a}$ & $3.40 \mathrm{a}$ & $3.57 \mathrm{a}$ & & $9.11 \mathrm{a}^{\mathrm{a}}$ & $10.87 \mathrm{a}$ & $8.99 \mathrm{a}$ & \\
\hline Analysis of variance & & $\mathrm{df}$ & SM & $\mathrm{P}$ & & df & SM & $\mathrm{P}$ & \\
\hline Age of the tissue (A) & & 2 & 0.08 & 0.17 & & 2 & 16.55 & 0.12 & \\
\hline Pathogen $(\mathrm{P})$ & & 2 & 0.18 & 0.02 & & 2 & 37.00 & 0.01 & \\
\hline $\mathrm{A} \times \mathrm{P}$ & & 4 & 0.07 & 0.22 & & 4 & 6.09 & 0.53 & \\
\hline
\end{tabular}

${ }^{1}$ Means in columns or rows followed by the same letters are not significantly different according to Tukey's test $(\mathrm{P}=0.05)$. The data describing necrotic length were transformed using $\log (\mathrm{x})$ prior to analysis, but the non-transformed data are presented. No lesions were detected on the control plants.

ended in dark brown vascular streaks (Figure $1 \mathrm{C}$, D). The effect of the pathogen, both on the length of necrosis and the length of the vascular necrotic streaks, was significant $(\mathrm{P} \leq 0.05)$, but the effect of the age of the inoculated tissue and the interaction between the age of the inoculated tissue and pathogen were not statistically significant (Table 4). Diplodia mutila and $D$. seriata produced the largest necrotic lesions and the largest vascular necrotic streaks. In both analyses, $B$. dothidea was less virulent; however, this phenomenon was not the case when this pathogen was inoculated on cuttings in the bio-testing for cultivar susceptibility (Table 3). Each Botryosphaeriaceae species was re-isolated from each inoculated grape plant and from the three types of tissue ages; there was $100 \%$ recovery for $D$. seriata and $93.3 \%$ recovery for D. mutila. Because no lesions were detected in the control plants, they were not included in the analysis.

\section{Discussion}

This study reports for the first time the presence of $D$. mutila and $S$. viticola associated with wood cankers and dieback of table grapes in Chile. At the same time, the presence of D. seriata was confirmed, although D. seriata (former B. obtusa) had been previously reported in 'Redglobe' table grapes showing decline (described as black dead arm) symptoms in Chile (Auger et al., 2004). Unlike previous studies (Larignon et al., 2001; Phillips, 2002; Úrbez-Torres et al., 2006), B. dothidea and many others species reported worldwide were not isolated from table grapes in the central zone of Chile. The high relative recovery of $D$. seriata from table grape cultivars showing symptoms of decline $(83.3 \%)$ in this study was similar to a previous report ( $86.0 \%$ of total samples) from Chile (Auger et al., 2004), and this finding was also similar to the results obtained by Luque et al. (2009), who found that D. seriata and Eutypa lata (Pers.) Tul. \& C. Tul. were predominantly isolated from V-shaped cankers in Spain. In our study, E. lata was not isolated, and to date there is no official report of $E$. lata affecting grapevines in Chile (Acuña, 2010).

The identification of Botryosphaeriaceae species was based primarily on morphological characteristics and was later confirmed by sequencing of the ITS1-5.8S-ITS2 region of the nuclear rDNA. The morphological results obtained agree with previously published descriptions of $D$. mutila, D. seriata and S. viticola (Denman et al., 2000; Luque et al., 2005; Taylor et al., 2005; ÚrbezTorres et al., 2006; Slippers et al., 2007; Phillips et al., 2007 and 2008). The teleomorphs of these species were not observed in this study.

Our results confirmed that $D$. mutila, D. seriata and $S$. viticola were pathogenic to grapevines, especially the pathogenicity tests performed on 25-year-old 'Flame Seedless' table grape plants. The wood symptoms caused by D. mutila in inoculated grapevines were in agreement with 
the original wood symptoms reported for BDA by Lehoczky (1974). D. mutila was re-isolated from necrotic tissue and vascular streaking, but foliar symptoms, such as leaf chlorosis, wilting, leaf reddishness and premature leaf fall, which had also been reported to be associated with D. mutila and other Botryosphaeriaceae (van Niekerk et al., 2006), were not observed in this study. Similarly, D. seriata and $S$. viticola only induced necrotic and vascular streaking in inoculated grapevines and were re-isolated from inoculated grapevines. Therefore, in agreement with other studies (Castillo-Pando et al., 2001; Taylor et al., 2005; Úrbez-Torres, 2011; Úrbez-Torres and Gubler, 2009; van Niekerk, 2004), these Botryosphaeriaceae species were pathogenic, and the occurrence of necrotic internal symptoms was demonstrated in this study. However, the association of these species with BDA and foliar symptoms remains to be determined.

Similarly, the V-shaped necrosis associated with Botryosphaeriaceae infections or in BDA in other studies (Luque et al., 2009; Úrbez-Torres, 2011) was not observed in inoculated plants. This outcome was attributed to the short incubation period because the grape plants were removed before bud burst early in the spring. In addition, these results do not discount the possibility that other fungal species associated with trunk and arm diseases elsewhere may coexist.

In pathogenicity tests performed by other authors, D. mutila and D. seriata were less virulent than B. dothidea (Phillips, 1998), and these species were considered weakly virulent in Australia (Taylor et al., 2005) and California (Úrbez-Torres et al., 2009). However, these previous findings may not apply to our results because $D$. mutila and $D$. seriata were the most aggressive of the species isolated from table grape plants in this study. This finding corresponds with the original description of BDA in that D. mutila was regarded as the cause of the disease (Lehoczky, 1974). Several reasons can explain these differences in virulence, including the isolate variability, inoculation conditions and grape cultivars used in these pathogenicity tests. In addition, it should be taken into account that the $B$. dothidea isolate was obtained from an avocado tree. Therefore, although $D$. mutila was isolated less frequently than $D$. seriata, the former species should be regarded as a major pathogen associated with BDA in Chile. However, additional investigations using a large number of isolates are needed to clarify this hypothesis.

The observation that BDA was more prevalent in older, as opposed to younger, table grape plants was also reported by Larignon et al. (2001), who found that grapevines over eight years old were affected (Northern Hemisphere). The highest prevalence of BDA was found in relatively old vineyards associated with Botryosphaeriaceae species (Figure 2). In this study, the importance of $D$. seriata is clear because it was the main species recovered from diseased grapevines affected by Botryosphaeria canker. Nevertheless, considering the results obtained in the inoculations performed in old tissues, D. mutila and D. seriata were the more aggressive species. However, it would be advisable to study a larger number of samples before making a final conclusion.

\section{Acknowledgments}

This work was funded by the project DI-PUCV 242-731/09. We thank E. Salgado for his support in performing the statistical analysis and his valuable comments on the manuscript; Mauricio Cisternas, for the phylogenetic analysis; V. Valdivieso and G. Gioia, for their valuable assistance in field trials; and G. Andrade and I. Cortés, for their assistance in laboratory trials and pathogenicity tests. 


\title{
Resumen
}

\begin{abstract}
A. Morales, B.A. Latorre, E. Piontelli y X. Besoain. 2012. Especies de Botryosphaeriaceae que afectan parronales de uva de mesa en Chile y susceptibilidad del cultivar. Cien. Inv. Agr. 39(3): 445-458. Diversas especies de Botryosphaeriaceae se han identificado como causantes de cancros y muerte regresiva en Vitis vinifera en diferentes regiones donde se cultivan vides en el mundo. Esta investigación tuvo el propósito de determinar nuevas especies de Botryosphaeriaceae asociadas a uva de mesa en Chile, determinar la incidencia y severidad de las especies de Botryosphaeriaceae asociadas al decaimiento de vides, evaluar la susceptibilidad de cultivares y determinar el efecto de la edad del tejido en el desarrollo de cancrosis y necrosis vascular. Los síntomas observados se caracterizaron por la presencia de brotes débiles y decaimiento generalizado de las vides. Internamente, se observaron cancros de color café en forma de o "U" ó de "V" y estrías necróticas vasculares. Aislados patogénicos de Diplodia seriata, D. mutila y Spencermartinsia viticola se obtuvieron consistentemente desde cancros en la madera y/o estrías vasculares, siendo $D$. seriata la especie más frecuentemente aislada (83,3\%). En parronales de uva de mesa de 11 a 20 años de edad, la incidencia de la enfermedad varió entre un 22,0 a un 69,0\%, y la severidad entre 6,0 y 21,8\%. Los cultivares de uva de mesa 'Thompson Seedless', 'Redglobe' y 'Flame Seedless' fueron igualmente susceptibles a infección por $D$. mutila, $D$. seriata y $S$. viticola. La edad de los tejidos inoculados no tuvo un efecto significativo en el desarrollo de la necrosis. Estos resultados constituyen la primera mención de D. mutila y $S$. viticola en vides en Chile.
\end{abstract}

Palabras clave: Diplodia, enfermedades, Spencermartinsia viticola, vid, Vitis vinifera.

\section{References}

Acuña, R. 2010. Compendio de bacterias y hongos de frutales y vides en Chile. Servicio Agrícola y Ganadero, División Protección Agrícola. Santiago, Chile. 150 pp.

Alves, A., A. Correia, J. Luque, and A.J.L. Phillips. 2004. Botryosphaeria corticola, sp. nov. on Quercus species, with notes and description of Botryosphaeria stevensii and its anamorph, Diplodia mutila. Mycologia 96:598-613.

Armengol, J., A. Vicent, L. Torné, F. García-Figueres, and J. García-Jiménez. 2001. Fungi associated with esca and grapevine declines in Spain: a three-year survey. Phytopathol. Mediterr. 40:325-329.

Auger, J., M. Esterio, G. Ricke, and I. Pérez. 2004. Black dead arm and canker of Vitis vinifera $\mathrm{cv}$. Red Globe caused by Botryosphaeria obtusa in Chile. Plant Dis. 88:1286.

Bulit, J., Y. Bugaret, and R. Lafon. 1972. L'excoriose de la vigne et ses traitements. Rev. Zool. Agric. Patol. Veg. 1:44-54.
Castillo-Pando, M., A. Somers, C.D. Green, M. Priest, and M. Sriskanthades. 2001. Fungi associated with dieback of Semillon grapevines in the Hunter Valley of New South Wales. Aust. Plant Pathol. 30:59-63.

Chamberlain, G.C., R.S. Willison, J.L. Towsend, and J.H. De Ronde. 1964. Two fungi associated with the dead arm disease of grapes. Can. J. Bot. 42:351-355.

Cristinzio, G. 1978. Gravi attachi di Botryosphaeria obtusa su vite provincial di Isernia. Inf. Fitopatol 28: 23-25.

Damm, U., P.W. Crous, and P.H. Fourie. 2007. Botryosphaeriaceae as potential pathogens of Prunus species in South Africa, with descriptions of $D i$ plodia africana and Lasiodiplodia plurivora sp. nov. Mycologia 99: 664-680.

Denman, S., P. W. Crous, J. E. Taylor, J-C Kang, I. Pascoe, and M.J. Wingfield. 2000. An overview of the taxonomic history of Botryosphaeria, and a re-evaluation of its anamorphs based on morphology and ITS rDNA phylogeny. Stud. Mycol. 45:129-140. 
Felsenstein, J. 1985. Confidence limits on phylogenies: an approach using the bootstrap. Evolution 39:783-791.

Katoh, K., K. Kuma, H. Toh, and T. Miyata. 2005. MAFFT version 5: improvement in accuracy of multiple sequence alignment. Nucl. Acid. Res. 33:511-518.

Larignon, P., and B. Dubos. 1997. Fungi associated with esca disease in grapevine. European Journal of Plant Pathology 103:147-157.

Larignon, P., R. Fulchic, L. Cere, and B. Dubos. 2001. Observation on black dead arm in French vineyards. Phytopathol. Mediterr. 40:336-342.

Latorre, B., X. Besoain, and V. Flores. 1986. Botryosphaeria canker on table grapes. Phytopatology 76:1112.

Lehoczky, L. 1974. Black dead-arm disease of the grapevine caused by Botryosphaeria stevensii infection. Acta Phytopathologica Academiae Scientiarum Hungaricae 9:319-327.

Luque, J., S. Martos, and A.J.L. Phillips. 2005. Botryosphaeria viticola $\mathrm{sp}$. nov. on grapevines: a new species with a Dothiorella anamorph. Mycologia 97:1111-1121.

Luque, J., S. Martos, A. Aroca, R. Raposo, and F. García-Figueres. 2009. Symptoms and fungi associated with declining mature grapevine plants in northeast Spain. J. Plant Pathol. 91:381-390.

Mc Kinney, H.H. 1923. Influence of soil temperature and moisture on infection of wheat seedlings by Helminthosporium sativum. Journal of Agricultural Research 26:195-225.

Moller, W.J., and A.N. Kasimatis. 1978. Dieback of grapevines caused by Eutypa armeniacae. Plant Dis. 62: 254-258.

Mugnai, L., A. Graniti, and G. Surico. 1999. Esca (black measles) and brown wood-streaking: two old and elusive diseases of grapevines. Plant Dis. 83:404-418.

NCBI. 2009. GenBank. National Center for Biotechnology Information, Bethesda, MD. Available online at: http:// www.ncbi.nlm.nih.gov (Website accessed: November 2009).

ODEPA. 2009. Estadísticas de la Agricultura Chilena. Oficina de Estudios y Políticas Agrarias, Go- bierno de Chile, Santiago, Chile. Available online at: http:// www.odepa.cl (Website accessed: November, 2009).

Phillips, A.J.L. 1998. Botryosphaeria dothidea and other fungi associated with excoriose and dieback of grapevines in Portugal. J. Phytophatol. 146:327-332.

Phillips, A.J.L. 2002. Botryosphaeria species associated with diseases of grapevines in Portugal. Phytopathol. Mediterr. 41:3-18.

Phillips, A.J.L., A. Alves, A. Correia, and J. Luque. 2005. Two new species of Botryosphaeria with brown, 1-septate ascospores and Dothiorella anamorphs. Mycologia 97:513-529.

Phillips, A.J.L., P.W. Crous, and A. Alves. 2007. Diplodia seriata, the anamorph of Botryosphaeria obtusa. Fungal Diversity 25:141-155.

Phillips, A. J. L. 2007. The Botryosphaeria cite Centro de Recursos Microbiológicos, Facultad de Ciências e Tecnologia, Universidade Nova de Lisboa, Caparica, Portugal. Available online at: www.crem.fct.unl.pt/ (Website accessed: July 12, 2012).

Phillips, A.J.L., A. Alves, S.R. Pennycook, P.R. Johnston, A. Ramaley, A. Akulov, and P.W. Crous. 2008. Resolving the phylogenetic and taxonomic status of dark-spored teleomorph genera in the Botryosphaeriaceae. Persoonia 21:29-55.

Slippers, B., P.W. Crous, S. Denman, T.A. Coutinho, B.D. Winfield, and M.J. Winfield. 2004. Combined multiple gene genealogies and phenotypic characteristics differentiate several species previously identified as Botryosphaeria dothidea. Mycologia 96:83-101.

Slippers, B., W.A. Smit, P.W. Crous, T.A. Coutinho, B.D. Wingfield, and M.J. Wingfield. 2007. Taxonomy, phylogeny and identification of Botryosphaeriaceae associated with pome and stone fruit trees in South Africa and other regions of the world. Plant Pathology 56:128-139.

Taylor, A., G.E.St.J. Hardy, P. Wood, and T. Burgess. 2005. Identification and pathogenicity of Botryosphaeria species associated with grapevine decline in Western Australia. Aust. Plant Pathol. 34:187-195. 
Trouillas, F.P., J.R. Úrbez-Torres, and W.D. Gubler. 2010. Diversity of diatrypaceous fungi associated with grapevine canker diseases in California. Mycologia 102:319-336.

Úrbez-Torres, J.R. 2011. The status of Botryosphaeriaceae species infecting grapevines. Phytopathol. Mediterr. 50:S5-S44.

Úrbez-Torres, J.R., and W.D. Gubler. 2009. Pathogenicity of Botryosphaeriaceae species isolated from grapevine cankers in California. Plant Dis. 93:584-592.

Úrbez-Torres, J.R., G.M. Leavitt, T.M. Voegel, and W.D. Gubler. 2006. Identification and distribution of Botryosphaeria spp. associated with grapevine cankers in California. Plant Dis. 90:1490-1503.

Úrbez-Torres, J.R., W.D. Gubler and J. Luque. 2007. First report of Botryosphaeria iberica and $B . v i$ ticola associated with grapevine decline in California. Plant Dis. 91:772.

Úrbez-Torres, J.R., G.M. Leavitt, J.C. Guerrero, J. Guevara and W.D. Gubler. 2008. Identification and pathogenecity of Lasiodiplodia theobromae and Diplodia seriata, the causal agents of bot canker disease of grapevines in Mexico. Plant Dis. 92:519-529.

van Niekerk, J.M., P.W. Crous, J.Z. Groenewald, P.H. Fourie, and F. Halleen. 2004. DNA phylogeny, morphology and pathogenicity of Botryosphaeria species on grapevines. Mycologia 96:781-798. van Niekerk, J.M., P.L. Fourie, F. Hallon, and P.W. Crous. 2006. Botryosphaeria spp. as grapevines trunk disease pathogens. Phytopathol. Mediterr. 45:S43-S54.

White, T.J., T. Bruns, S. Lee, and J. Taylor. 1990. Amplification and direct sequencing of fungal ribosomal RNA genes for phylogenetics. In: M.A.Innis, D.H. Gelfand, J.J. Sninsky, and T.J. White (eds.). PCR protocols: a Guide to Methods and Applications. Academic Press, San Diego, Ca, USA. p. 315-322. 